\title{
Acceptance of nanotechnology applications and satisfaction with food-related life in southern Chile Berta SCHNETTLER $^{1 *}$, Gloria CRISÓSTOMO ${ }^{1}$, Marcos MORA $^{2}$, Germán LOBOS ${ }^{3}$, Horacio MIRANDA ${ }^{1}$, Klaus G. GRUNERT ${ }^{4}$
}

\begin{abstract}
Given the increasing use of nanotechnology in food production and packaging, its acceptance was evaluated in Temuco, Chile, and different consumer segments were identified. Different brands of sunflower oil were used at different prices as a case study. A structured questionnaire was applied to 400 supermarket shoppers. It was determined that brand was more important than nanotechnology application in packaging and food, and more important than price. The consumers preferred an average priced oil with a manufacturer's brand with nanoparticles to reduce cholesterol, and packaging with nanoparticles to increase the shelf life of the product and to prevent the growth of microorganisms. Three consumer segments were distinguished by the cluster analysis. The largest segment (44\%) preferred the oil without nanotechnology. The second (35.2\%) preferred the oil with nanotechnology in the food and the packaging, and the greatest preference was for packaging with nanoparticles extension in the shelf life of the product. The third segment (20.8\%) had similar behavior, but it showed greater preference for the oil with nanoparticles that reduced cholesterol and for the packaging that prevented the growth of bacteria and viruses. The segments differed in terms of their satisfaction with food-related life and lifestyle. It was found that over $50 \%$ of the participants preferred oil with nanotechnology applications.
\end{abstract}

Keywords: nanotechnology in food; nanotechnology in packaging; satisfaction with food-related life.

\section{Introduction}

The last two decades have seen considerable research and development on new food technologies. One of the reasons for such interest in new food technologies is the anticipated range of benefits they can bring to the consumer and the food sector (Reisch et al., 2011). Nevertheless, the risks associated with consuming foods produced with these new technologies, such as nanotechnology, are still unknown (Reisch et al., 2011; Chaudhry et al., 2008) or have so far received little attention (Forbe et al., 2011).

A wide variety of nanotechnology applications has been developed in agriculture and in food production for different purposes, such as increasing food security, reducing the use of agricultural inputs, and improving packaging, processing, and nutrition (Miller, 2010) focusing on promoting sustainable agriculture and offering better quality foods (Gruère, 2012). Applications of food nanotechnology can be divided into four categories: food processing and functional product improvement; delivery and release of bioactive compounds and nutraceuticals; detection of pathogens and food safety improvement; and development of packaging systems that can positively affect product quality and shelf life (García et al., 2010). Foods and food packaging using nanotechnology have already been commercialized, though the number of products is still low. In the near future, nanotechnology may become increasingly important in the food sector since government agencies and industry have been investing considerable resources in its development and implementation (Frewer et al., 2011). There is evidence to suggest, however, that nanotechnology is still unknown to many people (Reisch et al., 2011; Siegrist, 2008; Hosseini et al., 2012).

Studies conducted in European countries indicate that consumers are still skeptical about buying foods produced using nanotechnology (Reisch et al., 2011; Siegrist et al., 2007, 2008; 2009; Stampfli et al., 2010; Bieberstein et al., 2013; Rollin et al., 2011). The results of these studies show that consumers perceive nanotechnology applications differently, and those that involve the use of nanotechnology in food packaging are more accepted than those that involve the use of nanotechnology in food processing (Siegrist et al., 2007, 2008; Stampfli et al., 2010; Bieberstein et al., 2013). Among the factors that affect acceptance of nanotechnology are the perceived risks and benefits (Siegrist et al., 2007, 2008; Stampfli et al., 2010), knowledge and information regarding nanotechnology (Frewer et al., 2011; Rollin et al., 2011; Roosen et al., 2011), trust in the food industry and government regulations (Frewer et al., 2011; Hosseini et al., 2012; Siegrist et al., 2007, 2008, 2009; Stampfli et al., 2010), and consumer demographics (Siegrist et al., 2007, 2008; Eurobarometer, 2006).

\footnotetext{
Received 3 Dec., 2013

Accepted 10 Jan., 2014 (006244)

Department of Farming and Livestock Production, Faculty of Farming, Livestock and Forestry Sciences, Universidad de La Frontera, Temuco, Chile,

e-mail: berta.schnettler@ufrontera.cl

2 Department of Agricultural Economics, Faculty of Agricultural Sciences, Universidad de Chile, Santiago, Chile

3 School of Commercial Engineering, Faculty of Enterprise Sciences, Universidad de Talca, Talca, Chile

${ }^{4}$ MAPP Centre for Research on Customer Relations in the Food Sector, Aarhus University, Aarhus, Denmark

${ }^{*}$ Corresponding author
} 
To our knowledge, studies on the acceptance of nanotechnology applied to food production are still scarce in developing countries. Recently, in a developing nation in South America, Schnettler et al. (2013a) compared the acceptance of a food produced with nanotechnology with the acceptance of genetically modified and conventionally produced food. These authors found that consumers preferred conventionally produced food. However, at the same time, they revealed consumer segments that are positive about the possibility of buying food produced with nanotechnology. Similarly, Schnettler et al. (2013b) found that, in general, the application of nanotechnology in food packaging was more accepted than that involving the use of nanotechnology in foods. Nonetheless, consumers' behavior in response to specific nanotechnological applications in food and food packaging is still unknown in South America countries, whose governments are also promoting the development of this new technology (Kay \& Shapira, 2009). Considering that there is evidence to suggest that acceptance of nanotechnology applications differs from country to country (Bieberstein et al., 2013), this study aims to evaluate the acceptance of different types of nanotechnology applications in food processing and food packaging, taking Chile as a case study in South American countries.

Present-day society is characterized by a growing awareness of the role played by food in improving consumers' well-being. Recent studies conclude that food is among the important domains of life which affect the subjective wellbeing of individuals (Grunert et al., 2007; Schnettler et al., 2013c). It has been reported that there is a relation between satisfaction with food-related life and preferences for different foods (Schnettler et al., 2010, 2011). Moreover, Schnettler et al. (2013b) found that consumers satisfied with their food-related life were in general more willing to purchase foods and packages produced with nanotechnology. Therefore, it is expected that the acceptance of nanotechnology applications specific to food processing and food packaging will differ according to consumer satisfaction with food-related life.

The aims of this study were: to evaluate acceptance of nanotechnology applications in sunflower oil and in food packaging by consumers in Temuco (Region of the Araucanía, Chile) to identify consumer segments in terms of their preferences and characterize them according to their knowledge of nanotechnology, socio-demographic characteristics, and their level of satisfaction with food-related life.

\section{Materials and methods}

\subsection{Sample}

A survey was carried out with a sample of 400 people, aged over eighteen, who were responsible for buying food for their households in Temuco, Araucanía Region, Chile. The number of people surveyed was obtained using the simple random sample formula for non-finite populations (N> 100,000; Temuco: 245,347 inhabitants, Census 2002), with $95 \%$ confidence and $5 \%$ estimated error with p and q 0.5 (Fernández, 2002).

\subsection{Data collection instrument}

A questionnaire with closed-ended questions was used to collect information to determine whether the respondents had information about nanotechnology and whether they understood its meaning (closed ended response: Yes, No). The questionnaire included the SWFL (Satisfaction with Food-related Life) scale. SWFL was proposed and tested by Grunert et al. (2007) in eight European countries (Cronbach's $\alpha: 0.81-0.85$ ); the five items on the scale are grouped in a single dimension: 1. Food and meals are positive elements, 2. I am generally pleased with my food, 3 . My life in relation to food and meals is close to ideal, 4 . With regard to food, the conditions of my life are excellent, 5 . Food and meals give me satisfaction in daily life. The respondents were asked to indicate their degree of agreement with these statements using a 6-point Likert scale (where 1 is disagree completely and 6 is agree completely).

Classification questions were included to establish gender, age, family size, self-declared lifestyle, occupation, and level of education of the head of the household, and possession of 10 household goods. These last two variables were meant to determine the socioeconomic group according to Adimark (2004): classified as ABC1 (high and upper middle), C2 (middlemiddle), C3 (lower middle), D (low), and E (very low).

In order to determine the preferences for different nanotechnology applications in sunflower oil and its packaging, conjoint analysis (CA) was performed. This is a decomposition method that allows the relative importance of the attributes of a product to be estimated, as well as the part-worth utility values for each level of an attribute. The estimated part-worth utility indicates the influence of each level of an attribute on consumer preferences for a particular combination, i.e. they represent the degree of preference for each level of an attribute (Hair et al., 1999). Additionally, the attributes brand and price were included since both reduce the risks associated with purchase. For the attribute brand, two manufacturer' brands were established (Chef and Natura) and a store brand of a major supermarket chains in Chile (Jumbo). For the attribute nanotechnology application in the food, the following levels were defined: without application, with nanoparticles to reduce blood cholesterol, and with nanoparticles to increase the absorption of minerals and vitamins. As for nanotechnology application in the packaging, the following levels were defined: without application, with nanoparticles that extend product shelf life, and with nanoparticles that prevent the development of bacteria and viruses. The price levels were established based on current prices in the Temuco market for a $1 \mathrm{~L}$ bottle of sunflower oil at the time of the survey: US\$ 2.5 , US\$ 2.7 and US\$ 3.1. The national currency values (Chilean pesos) were converted to dollars using the average 2011 value ( $\$ 483.67 /$ US\$). From these attributes and levels, a total of 81 combinations $(3 \times 3 \times 3 \times 3)$ were obtained; however, to facilitate the respondents' answers, it was decided that a fractional factorial design would be used obtained with the macro MktEx from the SAS Institute (Kuhfeld, 2012). This allowed the number of stimuli to be reduced to twelve with one specification for each attribute (Table 1). Each participant ranked twelve cards from most to least preferred using a scale from 1 to 12 , where $1=$ most preferred; $12=$ least preferred. 
Table 1. Design of the conjoint experiment.

\begin{tabular}{|c|c|c|c|c|}
\hline Card & Brand & Nanotechnology in food & Nanotechnology in packaging & $\begin{array}{c}\text { Price } \\
\text { US\$/L }\end{array}$ \\
\hline A & Chef & Without & Without & 2.5 \\
\hline $\mathrm{B}$ & Chef & Without & Nanoparticles to increase the duration of the product & 2.7 \\
\hline $\mathrm{C}$ & Chef & Nanoparticles to reduce cholesterol & Nanoparticles to prevent the growth of bacteria and viruses & 3.1 \\
\hline $\mathrm{D}$ & Chef & Nanoparticles to increase the absorption of minerals and vitamins & Nanoparticles to prevent the growth of bacteria and viruses & 2.7 \\
\hline $\mathrm{E}$ & Natura & Without & Without & 3.1 \\
\hline $\mathrm{F}$ & Natura & Without & Nanoparticles to prevent the growth of bacteria and viruses & 2.5 \\
\hline G & Natura & Nanoparticles to reduce cholesterol & Without & 2.7 \\
\hline $\mathrm{H}$ & Natura & Nanoparticles to increase the absorption of minerals and vitamins & Nanoparticles to increase the duration of the product & 2.5 \\
\hline I & Jumbo & Without & Without & 2.7 \\
\hline $\mathrm{J}$ & Jumbo & Without & Nanoparticles to prevent the growth of bacteria and viruses & 2.1 \\
\hline $\mathrm{K}$ & Jumbo & Nanoparticles to reduce cholesterol & Nanoparticles to increase the duration of the product & 2.1 \\
\hline $\mathrm{L}$ & Jumbo & Nanoparticles to increase the absorption of minerals and vitamins & Without & 3.1 \\
\hline
\end{tabular}

Prior to asking the respondents to put the cards in order, the definition used by Siegrist et al. (2008) was read to them: "Nanotechnology is considered one of the key revolutionizing technologies of the $21^{\text {st }}$ century and refers to a broad range of advanced applications that deal with particles and structures smaller than $100 \mathrm{~nm}$. One nanometer is one billionth of a meter. The breadth of possible fields of application is farreaching and includes, for example, energy and information technologies as well as the medical and cosmetics industries. In the near future, the food industry plans to realize the potentials of nanotechnology to extend shelf life, customize flavors, or improve human health and well-being. Along with the beneficial aspects, nanotechnology also carries possible risks that we know little about. The biggest worry among experts is that nanoparticles may permeate the human body. The effects of nanoparticles on human health and the environment are still widely unknown".

\subsection{Survey procedures}

The survey was applied in April and July 2011 in person by two previously trained interviewers in three supermarkets in Temuco. People coming out of the supermarket were given the questionnaire and the purpose of the survey as well as the strictly confidential treatment of the information obtained were explained. They were then asked if they were prepared to answer the questionnaire. Prior to the application of the survey, the questionnaire was validated by a preliminary test with $10 \%$ of the survey sample. Since the validation of the instrument was satisfactory, no changes were required in either the questionnaire or the interview procedure. The participants signed an informed consent statement before responding. The present study was approved by the Bio-ethics Committee of the Universidad de La Frontera.

\subsection{Statistical analysis}

Conjoint analysis was carried out using the TRANSREG procedure by SAS (SAS Institute Inc., Cary, NC, USA). The relative importance that consumers gave to the different attributes and the utility values obtained for each level of the selected factors were determined. The Root Mean Square Error (RMSE) was calculated to measure the difference between the observed and the predicted data (Kuhfeld, 2012). A hierarchical cluster analysis was chosen to determine consumer segments according to the partial utility scores of the attribute levels. Ward's procedure, which calculates the squared Euclidean distance, was carried out using the CLUSTER procedure by SAS. The number of clusters was based on the $\mathrm{R}^{2}$ obtained and the significant increase in the Cubic Criterion of Clustering and Pseudo-F values. To describe the segments, the Chi-square test was applied to the discrete variables and a one-factor analysis of variance to the continuous variables ( $99 \%$ and $95 \%$ confidence level). Since the Levene's statistic indicated non-homogeneous variances in all of the continuous variables analyzed, the variables for which the analysis of variance resulted in significant differences $(\mathrm{P}<0.001)$ were subjected to Dunnett's T3 multiple comparisons test.

\section{Results}

Table 2 shows a sample description. Most respondents were: women (64.5\%); people between 35 and 54 years of age (50.2\%); people from families with three or four members (59.5\%); private-sector employees $(51.0 \%)$; people from the $\mathrm{ABC} 1$ socio-economic group (41.0\%); people residing in urban areas (95.8\%); and people with a conservative lifestyle (56.5\%). Great number of respondents declared not having any previous information about nanotechnology (68.8\%), or not knowing its meaning $(72.5 \%)$. With respect to the SWFL using principal components analysis, the existence of a single factor was obtained for all the items with $60.8 \%$ of the variance explained. The Cronbach's a coefficient obtained (0.821) indicates an adequate level of internal consistency and makes it possible to conclude that this is a reliable scale (Hair et al., 1999). The majority of the respondents were satisfied (51.3\%) and extremely satisfied (34.2\%) with their food-related life.

According to the conjoint analysis (Table 3), for the entire sample, the attribute of greatest importance during the purchase process was brand, followed by the type of nanotechnology application in the packaging and in the food, and finally, 
Table 2. Characteristics (\%) of the sample. Temuco, Chile. July 2011.

\begin{tabular}{|c|c|c|}
\hline Sample & Composition & $\%$ \\
\hline \multirow{2}{*}{ Gender } & Female & 64.5 \\
\hline & Male & 35.5 \\
\hline \multirow{3}{*}{ Age } & $<35$ years & 23.8 \\
\hline & $35-54$ years & 50.2 \\
\hline & 55 years or older & 26.0 \\
\hline \multirow{3}{*}{ Family size } & $1-2$ members & 26.3 \\
\hline & 3-4 members & 59.5 \\
\hline & 5 members or more & 14.2 \\
\hline \multirow{7}{*}{ Occupation } & Independent worker & 7.2 \\
\hline & Businessperson & 11.8 \\
\hline & Private-sector worker & 51.0 \\
\hline & Public-sector worker & 17.2 \\
\hline & Retired & 12.0 \\
\hline & Unemployed & 0.3 \\
\hline & Other & 0.5 \\
\hline \multirow{4}{*}{ Socio-economic status } & ABC1 (high and upper middle) & 41.0 \\
\hline & C2 (middle-middle) & 25.3 \\
\hline & C3(lower middle) & 23.5 \\
\hline & $\mathrm{D}(\mathrm{low})$ & 10.2 \\
\hline \multirow{2}{*}{ Residence } & Rural & 95.8 \\
\hline & Urban & 4.2 \\
\hline \multirow{5}{*}{ Lifestyle } & Conservative & 56.5 \\
\hline & Liberal & 11.3 \\
\hline & Ecological & 6.0 \\
\hline & Athletic & 12.3 \\
\hline & Innovative & 13.8 \\
\hline \multirow{2}{*}{$\begin{array}{l}\text { Have received information } \\
\text { regarding nanotechnology }\end{array}$} & Yes & 31.2 \\
\hline & No & 68.8 \\
\hline \multirow{3}{*}{$\begin{array}{c}\text { Knows the meaning of } \\
\text { nanotechnology }\end{array}$} & Yes & 27.5 \\
\hline & No & 72.5 \\
\hline & Unsatisfied & 3.3 \\
\hline \multirow{3}{*}{$\begin{array}{l}\text { Satisfaction with } \\
\text { food-related life }\end{array}$} & Somewhat satisfied & 11.3 \\
\hline & Satisfied & 51.3 \\
\hline & Extremely satisfied & 34.2 \\
\hline
\end{tabular}

price. The signs of the utility values indicate preference for manufacturers' brands. Likewise, preference was observed for both types of nanotechnology applications in the packaging. The consumers preferred the oil with nanoparticles to reduce blood cholesterol over the products with no nanotechnology applications and that with nanoparticles that increase the absorption of minerals and vitamins. Consumers' first choice was the mid-level priced oil, followed by the one with the lowest price. The RMSE of the conjoint analysis was 0.21.

Cluster analysis distinguished three consumer groups with statistically significant differences in terms of importance assigned to the brand, nanotechnology application in the food and price $(\mathrm{P} \leq 0.001)$. The groups also differed in terms of preference for brands, nanotechnology applications in the food and in the packaging, and price levels $(\mathrm{P} \leq 0.001)$ (Table 3 ). The groups differed significantly (Table 4 ) in terms of level of satisfaction with food-related life and self-declared lifestyle
$(\mathrm{P} \leq 0.05)$. The main characteristics of the groups obtained are described next.

Prone to nanotechnology. Group 1 (20.8\%): assigned greatest importance to the type of nanotechnology application in the food, significantly more than that assigned by the other groups. This group rejected the oil without nanotechnology and preferred the alternatives with nanotechnology applications in the food and packaging. This group stood out for the significantly greater preference for oil with nanoparticles to reduce the cholesterol level and for the packaging with the nanoparticles that prevents the development of bacteria and viruses (Table 3 ).

Sensitive to the brand, prefer conventional oil. Group 2 (44.0\%): placed great importance to brand, similar to Group 3 but significantly higher than Group 1, with a preference for the brand Chef, significantly stronger than the other groups. Group 2 preferred the oil with no nanotechnology application in either the food or the packaging, significantly stronger than the other groups. Nevertheless, this group showed a preference for the oil with nanoparticles to reduce cholesterol content, statistically similarly to Group 3. Group 2 was the only one that preferred the lowest-priced oil, which indicates that there is no association between price and quality (Table 3 ). Group 2 presented less number of people extremely satisfied with their food-related life $(25.6 \%)$ and the greatest presence of people who identified themselves as having a conservative lifestyle (67.6\%) (Table 4).

Sensitive to brand, prone to nanotechnology. Group 3 (35.2\%): also gave the greatest importance to brand, but the preference for the brand Natura was significantly greater than that of the other groups. This group rejected the oil without nanotechnology in the food and in the packaging, showing a preference for the two types of nanotechnology applications in the food and for nanotechnology applications in the packaging. It stood out for the great preference for the packaging with nanoparticles that increase the product's shelf life, significantly greater than the other groups. Group 3 was the only one that preferred the highest price, which indicates that these consumers associate higher price with better quality (Table 3 ). This group had a higher number of people extremely satisfied with their food-related life (47.5\%), and with an innovative lifestyle (21.3\%) (Table 4).

The three groups preferred the manufacturers' brands and rejected the store brand. This result and the greater importance assigned to the brand in the total sample and in Groups 2 and 3 indicate that consumers use this attribute to reduce the risk associated with purchasing foods produced with a new technology, such as nanotechnology, and prefer the product of a recognized brand. The alternative that concentrated the greatest number of first and second preference scores (36\%) was the brand Chef with nanoparticles to reduce cholesterol with a package with nanoparticles that prevent the development of bacteria and viruses, at the highest price. If it is considered that Chef is the brand that has been available in the Chilean market longer than the brand Natura, the importance that trust in the brand has in the food choice was confirmed. 
Table 3. Distribution and relative importance for the three clusters and overall sample based on preferences for sunflower oil.

\begin{tabular}{|c|c|c|c|c|c|c|}
\hline Attribute \& Levels & $\begin{array}{c}\text { Total } \\
\text { sample } \\
(\mathrm{n}=400) \\
\end{array}$ & $\begin{array}{l}\text { Group } 1 \\
(\mathrm{n}=83)\end{array}$ & $\begin{array}{l}\text { Group } 2 \\
(\mathrm{n}=176)\end{array}$ & $\begin{array}{c}\text { Group } 3 \\
(\mathrm{n}=141)\end{array}$ & $\mathrm{F}$ & $\mathrm{P}$ \\
\hline \multicolumn{7}{|l|}{ Brand } \\
\hline National Brand (Chef) & 0.998 & $0.445 \mathrm{~b}$ & $1.869 \mathrm{a}$ & $0.229 \mathrm{~b}$ & 70.276 & $0.000^{\star *}$ \\
\hline National brand (Natura) & 1.101 & $0.945 \mathrm{ab}$ & $0.432 \mathrm{~b}$ & $2.024 \mathrm{a}$ & 53.420 & $0.000^{* *}$ \\
\hline Store brand (Jumbo) & -2.253 & $-1.391 \mathrm{a}$ & $-2.301 b$ & $-2.254 \mathrm{~b}$ & 13.753 & $0.000^{* *}$ \\
\hline Relative importance (\%) & 33.9 & $23.4 \mathrm{~b}$ & $37.4 \mathrm{a}$ & $35.5 \mathrm{a}$ & 24.355 & $0.000^{* *}$ \\
\hline \multicolumn{7}{|l|}{ Nanotechnology in food } \\
\hline Without nanotechnology in food & -0.399 & $-2.484 \mathrm{c}$ & $0.613 \mathrm{a}$ & $-0.464 b$ & 167.590 & $0.000^{* *}$ \\
\hline Nanoparticles to reduce cholesterol & 0.661 & $2.194 \mathrm{a}$ & $0.241 \mathrm{~b}$ & $0.304 \mathrm{~b}$ & 84.910 & $0.000^{* *}$ \\
\hline Nanoparticles to increase the absorption of minerals and vitamins & -0.262 & $0.289 \mathrm{a}$ & $-0.854 \mathrm{~b}$ & 0.159 a & 39.413 & $0.000^{* *}$ \\
\hline Relative importance (\%) & 23.6 & $37.6 \mathrm{a}$ & $21.4 \mathrm{~b}$ & $18.3 \mathrm{~b}$ & 83.454 & $0.000^{* *}$ \\
\hline \multicolumn{7}{|l|}{ Nanotechnology in packaging } \\
\hline Without nanotechnology in packaging & -0.347 & $-1.545 b$ & $1.278 \mathrm{a}$ & $-1.687 \mathrm{~b}$ & 253.533 & $0.000^{* *}$ \\
\hline Nanoparticles to increase the duration of the product & 0.177 & $0.175 \mathrm{~b}$ & $-0.492 \mathrm{c}$ & $1.013 \mathrm{a}$ & 63.800 & $0.000^{* *}$ \\
\hline Nanoparticles to prevent the growth of bacteria and viruses & 0.170 & $1.371 \mathrm{a}$ & $-0.786 \mathrm{c}$ & $0.673 \mathrm{~b}$ & 152.422 & $0.000^{* *}$ \\
\hline Relative importance (\%) & 24.6 & 25.8 & 23.2 & 25.8 & 2.332 & 0.098 \\
\hline \multicolumn{7}{|l|}{ Price } \\
\hline US\$/L 2.5 & 0.081 & $0.128 \mathrm{~b}$ & $0.839 \mathrm{a}$ & $-0.891 \mathrm{c}$ & 91.609 & $0.000^{* *}$ \\
\hline US\$/L 2.7 & 0.409 & $0.261 \mathrm{a}$ & $-0.353 \mathrm{~b}$ & $0.427 \mathrm{a}$ & 27.618 & $0.000^{* *}$ \\
\hline US\$/L 3.1 & -0.130 & $-0.389 \mathrm{~b}$ & $-0.486 \mathrm{c}$ & $0.464 \mathrm{a}$ & 22.618 & $0.000^{* *}$ \\
\hline Relative importance (\%) & 17.9 & $13.2 \mathrm{~b}$ & $18.0 \mathrm{ab}$ & $20.4 \mathrm{a}$ & 9.233 & $0.000^{\star *}$ \\
\hline
\end{tabular}

Root-mean-square error $(\mathrm{RMSE})=0.21{ }^{* *}$ Significant at $1 \%$. Different letters in the line indicate significant differences according to Dunnett's T3 multiple comparison test ( $\left.\mathrm{p} \leq 0.001\right)$.

"a" is significantly higher than "b". "b" is significantly higher than "c".

Table 4. Characteristics (\%) with significant differences in the groups of buyers identified by cluster analysis in Temuco. Chile.

\begin{tabular}{cccc}
\hline Characteristic & Group 1 $(\mathrm{n}=83)$ & Group 2 (n=176) & Group 3 (n=141) \\
\hline Satisfaction with food-related life & & $\mathrm{P}=0.002$ & 1.4 \\
\hline Unsatisfied & 6.2 & 3.4 & 7.8 \\
Somewhat satisfied & 13.6 & 13.1 & 43.3 \\
Satisfied & 50.6 & 58.0 & 47.5 \\
Extremely satisfied & 29.6 & 25.6 & 45.4 \\
\hline Lifestyle & & $\mathrm{P}=0.002$ & 15.6 \\
Conservative & 51.9 & 67.6 & 6.4 \\
Liberal & 12.3 & 7.4 & 11.3 \\
Ecological & 4.9 & 6.2 & \\
Athletic & 18.5 & 10.2 & 21.3 \\
Innovative & 12.3 & 8.5 & \\
\hline
\end{tabular}

P value corresponds to the (bilateral) asymptotic significance obtained in Pearson's Chi squared Test.

\section{Discussion}

Consumer perception of new products must be considered from the beginning of their development (Siegrist et al., 2008, 2009). Accordingly, the present study contributes to the knowledge of the acceptance of specific nanotechnology applications in a developing country, an aspect that has not been previously evaluated. It was observed that brand was the attribute of greatest relative importance, followed by the type of nanotechnology application in the packaging and in the food, and finally, by price in the purchase of sunflower oil, with a preference for the product with manufacturers' brands, nanoparticles in the oil to reduce cholesterol, with nanoparticles in the package to extend product shelf life, and to prevent the development of bacteria and viruses, at an average price.
Partly, these results are consistent with the greater acceptance for packages with nanotechnology than for foods with nanotechnology in developed countries (Siegrist et al., 2008; 2009; Stampfli et al., 2010; Bieberstein et al., 2013). However, the rejection of the alternative without nanotechnology in either the food or the package is noteworthy, in contrast to the results found in developed countries, which indicate that consumers prefer foods produced conventionally (Siegrist et al., 2007, 2008, 2009; Stampfli et al., 2010; Bieberstein et al., 2013). This behavior was only observed in one of the consumer segments identified in this study, Group 2 (44\%).

Given that the acceptance of foods produced with new technologies is directly associated with the risks and benefits perceived by the consumers (Frewer et al., 2011; Siegrist et al., 
2007, 2008; Rollin et al., 2011), the results obtained suggest that participants placed greater importance to the possible benefits associated with nanotechnology and less to the possible risks since the definition of nanotechnology given prior to the presentation of the stimuli from the conjoint analysis included both aspects. Indeed, a significant portion of the sample (Groups 1 and 3; $56 \%)$ preferred the oil with nanotechnology applications in the product and the packaging. This contradicts the findings of Siegrist et al. (2008) regarding consumers being able to perceive new technologies applied to food production as riskier than food processed with traditional products. One noteworthy aspect is the complete acceptance of the oil produced with nanoparticles that reduces cholesterol, which is consistent with the acceptance of beef from an animal genetically modified for the same purpose, according to a previous study in Chile (Schnettler et al., 2010). This indicates that certain benefits associated with new technologies in food production may be perceived more positively than others. Nevertheless, this result contradicts those obtained by Roosen et al. (2011) in Germany, where the information on the health benefits associated with nanotechnology food decreased its acceptance. This indicates differences between consumers in developed and developing countries.

The generalized preference for manufacturers' brands and the rejection of the store brand are consistent with the results of a previous study in Chile, which evaluated the acceptance of tomato sauce produced with genetically modified raw materials (Schnettler et al., 2008). This indicates that the brand helps to reduce the risk of buying foods produced with new technologies, such as biotechnology and nanotechnology. Likewise, it has been shown that consumer trust in the food industry plays an important role in the acceptance of these new technologies (Frewer et al., 2011; Siegrist et al., 2008; 2009; Stampfli et al., 2010; Bieberstein et al., 2013; Rollin et al., 2011). Price can also be used to reduce the risk associated with the purchase process; however, this behavior was only observed in Group 3 (35.2\%), which showed the greatest preference for the highest price.

Although it was possible to confirm the lack of existing knowledge of nanotechnology in the total sample (Hosseini et al., 2012; Siegrist et al., 2008), no differences were observed in the identified segments, contrary to what has been reported in developed countries (Frewer et al., 2011; Bieberstein et al., 2013; Rollin et al., 2011). Furthermore, no demographic differences between the groups were detected, in contrast to studies that have found differences associated with consumer's gender and age (Siegrist et al., 2008; Eurobarometer, 2006).

The differences in lifestyle reported by the participants is noteworthy because the segment that preferred the conventional oil (Group 2; 44.0\%) had the highest number of people who identified themselves as conservative. This is consistent with the findings of previous studies on the acceptance of genetically modified food (GMF) and nanotechnology applications. In these studies, a greater rejection of GMF (Schnettler et al., 2010, 2008; Nayga et al., 2006) and nanotechnology foods and packaging (Schnettler et al., 2013b) was observed for people with a conservative lifestyle

The differences in the level of satisfaction with food-related life among the identified groups confirm that preference for foods (Schnettler et al., 2010, 2011) and specifically for the use of nanotechnology in foods are related to satisfaction with food-related life (Schnettler et al., 2013b). The smallest number of people extremely satisfied with their food in Group 2 and the greater number of people extremely satisfied with their foodrelated life in Group 3 indicate that people with a high level of subjective well-being with respect to food are more receptive to the use of new technologies in food production. This suggests that people extremely satisfied with their food-related life experience pleasure when faced with the possibility of trying novel foods. Nevertheless, because this was not observed in Group 1, further studies are necessary to delve more deeply into this relationship. However, these results suggest that when investigating the acceptance of nanotechnology applications, a large number of consumer-related variables should be considered, such as their psychographic and psychological characteristics, and should not be confined solely to their demographic characteristics.

One of the limitations of the present study is that it was conducted in the context of one country only, Chile. Therefore, considering that the acceptance of new technologies applied to food production differs between developing countries (Mucci et al., 2004; De Steur et al., 2010), new research in developing countries from different regions of the world is necessary to confirm the results found here. Another limitation of this study is that the sample is not representative of the country's population distribution. However, the consumer distribution in the survey was similar to that in the samples defined by Schnettler et al. $(2010,2011,2008)$ in studies on supermarket consumers. Therefore, although the results and conclusions of the present study may not be applicable to the whole population, they might be valid for consumers that normally purchase foods from supermarkets.

\section{Conclusions}

In the Araucanía Region, Chile, it was found in the total sample that brand was the attribute of greatest relative importance, followed by the type of nanotechnology application in the packaging and in the food, and finally, price. Three consumer segments were identified with different profiles: satisfaction with food-related life and lifestyle. The largest segment (44\%) preferred oil without nanotechnology; the second (35.2\%) and third (20.8) segments preferred oil with nanotechnology in the food and the packaging, but they differed with respect to their preference for the types of nanotechnology applications. This bodes well for the introduction of foods produced with nanotechnology onto the domestic market but they must be endorsed by well-known manufacturers'brands.

\section{Acknowledgments}

The results presented correspond to Fondecyt Project 1100611.

\section{References}

Adimark. Mapa socioeconómico de Chile. (2004). Retrieved from: http://www.adimark.cl/medios/estudios/informe_mapa_ socioeconomico_de_chile.pdf 
Bieberstein, A., Roosen, J., Marette, S., Blanchemanche, S., \& Vandermoere, F. (2013). Consumer choices for nano-food and nanopackaging in France and Germany. European Review of Agricultural Economics, 40(1), 73-94. http://dx.doi.org/10.1093/erae/jbr069

Chaudhry, Q., Scotter, M., Blackburn, J., Ross, B., Boxall, A., Castle, L., Aitken, R., \& Watkins, R. (2008). Applications and implications of nanotechnologies for the food sector. Food Additives and Contaminants, 25(3), 241-258. http://dx.doi. org/10.1080/02652030701744538

De Steur, H., Gellynck, X., Storozhenko, S., Liqun, G., Lambert, W., Van Der Straeten, D., \& Viaene, J. (2010). Willingness-to-accept and purchase genetically modified rice with high folate content in Shanxi Province, China. Appetite, 54(1), 118-125. http://dx.doi. org/10.1016/j.appet.2009.09.017

Eurobarometer. (2006). Risk issues. Special eurobarometer 238/Wave 64.1. Brussels: TNS Opinion \& Social.

Fernández, A. (2002). Investigación y técnicas de mercado (1rd ed.). Madrid: Editorial Esic.

Forbe, T., García, M., \& Gonzalez, E. (2011). Potencial risks of nanoparticles. Ciência e Tecnologia de Alimentos, 31(4), 835-842.

Frewer, L. J., Bergmann, K., Brennan, M., Lion, R., Meertens, R., Rowe, G., Siegrist, M., \& Vereijken, C. (2011). Consumer response to novel agri-food technologies: implications for predicting consumer acceptance of emerging food technologies. Trends in Food Science \& Technology, 22(8), 442-456. http://dx.doi.org/10.1016/j. tifs.2011.05.005

García, M., Forbe, T., \& Gonzalez, E. (2010). Potential application of nanotechnology in the agro-food sector. Ciência e Tecnologia de Alimentos, 30(3), 573-581. http://dx.doi.org/10.1590/S010120612010000300002

Gruère, G. (2012). Implications of nanotechnology growth in food and agriculture in OECD countries. Food Policy, 37(2), 191-198. http:// dx.doi.org/10.1016/j.foodpol.2012.01.001

Grunert, K., Dean, D., Raats, M., Nielsen, N., \& Lumbers M. ( 2007). A measure of satisfaction with food-related life. Appetite, 49(2), 486-93. http://dx.doi.org/10.1016/j.appet.2007.03.010

Hair, J., Anderson, R., Tatham, R., \& Black, W. (1999). Análisis multivariante. Otero (5rd. ed.). Madrid: Prentice Hall Internacional.

Hosseini, A., Goddard, E., Vandermoere, F., Blanchemanche, S., Bieberstein, A., Marette, S., \& Roosen, J. (2012) Do environmental attitudes and food technology neophobia affect perceptions of the benefits of nanotechnology? International Journal of Consumer Studies, 36(2), 149-157. http://dx.doi.org/10.1111/j.14706431.2011.01090.x

Kay, L., \& Shapira, F. (2009). Developing nanotechnology in Latin America. Journal of Nanoparticle Research, 11(2), 259-278. http:// dx.doi.org/10.1007/s11051-008-9503-z

Kuhfeld, W. (2012). Marketing research methods in SAS. Experimental design, choice, conjoint and Graphical techniques. SAS 9.2 Edition. Retrieved from: http://support.sas.com/techsup/technote/mr2010. pdf

Miller, D. (2010). Food nanotechnology: new leverage against iron deficiency. Nature Nanotechnology, 5(5), 318-319. http://dx.doi. org/10.1038/nnano.2010.91

Mucci, A., Hough, G., \& Ziliani, C. (2004). Factors that influence purchase intent and perceptions of genetically modified foods among Argentine consumers. Food Quality and Preference, 15(6), 559-567. http://dx.doi.org/10.1016/j.foodqual.2004.02.004

Nayga, R. M., Fisher, M., \& Onyango, B. (2006). Acceptance of genetically modified food: comparing consumer perspectives in the United States and South Korea. Agricultural Economics, 34(3), 331-341. http://dx.doi.org/10.1111/j.1574-0864.2006.00129.x
Reisch, L., Scholl, G., \& Bietz, S. (2011). Better safe than sorry: consumer perceptions of and deliberations on nanotechnologies. International Journal of Consumer Studies, 35(6), 644-654. http:// dx.doi.org/10.1111/j.1470-6431.2010.00979.x

Rollin, F., Kennedy, J., \& Wills, J. (2011). Consumers and new food technologies. Trends in Food Science \& Technology, 22(2-3), 99-111. http://dx.doi.org/10.1016/j.tifs.2010.09.001

Roosen, J., Bieberstein, A., Marette, S., Blanchemanche, S., \& Vandermoere, F. (2011). The effect of information choice and discussion on consumers' willingness-to-pay for nanotechnology in food. Journal of Agricultural and Resource Economics, 36(2), 365-374.

Schnettler, B., Avila, R., Sepúlveda, N., Miranda, H., Sepúlveda, J., \& Denegri, M. (2010). Preference for beef with different types of genetic modification in Temuco, La Araucanía Region, Chile. Revista Cientifica-Facultad de Ciências Vererinarias, 20(5), 537-545.

Schnettler, B., Crisóstomo, G., Mills, N., Miranda, H., Mora, M., Lobos, G., \& Grunert, K. G. (2013a). Preferences for sunflower oil produced conventionally, produced with nanotechnology or genetically modified in the Araucanía Region of Chile. Ciencia e Investigación Agraria, 40(1), 17-29. http://dx.doi.org/10.4067/ S0718-16202013000100002

Schnettler, B., Crisóstomo, G., Sepúlveda, J., Mora, M., Lobos, G., Miranda, H., \& Grunert, K. G. (2013b). Food neophobia, nanotechnology and satisfaction with life. Appetite, 69, 71-79. http:// dx.doi.org/10.1016/j.appet.2013.05.014

Schnettler, B., Miranda, H., Sepúlveda, J., Denegri, M., Mora, M., Lobos, G., \& Grunert, K. G. (2013c). Psychometric properties of the Satisfaction with Food-Related Life Scale: application in southern Chile. Journal of Nutrition Education and Behavior, 45(5), 443-449. http://dx.doi.org/10.1016/j.jneb.2012.08.003

Schnettler, B., Reyes, P., Henríquez, J., Ruff, P., Sepúlveda, J., Denegri, M., Miranda, H., Sepúlveda, N., \& Lobos, G. (2011). Preferences for Lamb's Meat in Supermarkets in Temuco, La Araucanía Region, Chile. Revista Cientifica-Facultad de Ciências Vererinarias, 20(5), 537-545.

Schnettler, B., Sepúlveda, O., Ruiz, D., \& Denegri, M. (2008). Differentiated perception of transgenic tomato sauce in the southern Chile. Archivos Latinoamericanos de Nutricion, 58(1), 49-58.

Schnettler, B., Shene, C., Rubilar, M., Miranda, H., Sepúlveda, J., Denegri, M., \& Lobos, G. (2010). Acceptance of yoghurt with different functional ingredients among consumers in supermarkets in southern Chile. Archivos Latinoamericanos de Nutricion, 60(4), 380-390.

Siegrist, M. (2008). Factors influencing public acceptance of innovative food technologies and products. Trends in Food Science \& Technology, 19(11), 603-608. http://dx.doi.org/10.1016/j. tifs.2008.01.017

Siegrist, M., Cousin, M., Kastenholz, H., \& Wiek, K. (2007). Public acceptance of nanotechnology foods and food packaging: the influence of affect and trust. Appetite, 49(2), 459-466. http://dx.doi. org/10.1016/j.appet.2007.03.002

Siegrist, M., Stampfli, N., \& Kastenholz, H. (2009). Acceptance of nanotechnology foods: a conjoint study examining consumers' willingness to buy. British Food Journal, 111(7), 660-668. http:// dx.doi.org/10.1108/00070700910972350

Siegrist, M., Stampfli, N., Kastenholz, H., \& Keller, C. (2008). Perceived risks and perceived benefits of different nanotechnology foods and nanotechnology food packaging. Appetite, 51(2), 283-290. http:// dx.doi.org/10.1016/j.appet.2008.02.020

Stampfli, N., Siegrist, M., \& Kastenholz, H. (2010). Acceptance of nanotechnology in food and food packaging: a path model analysis. Journal of Risk Research, 13(3), 353-365. http://dx.doi. org/10.1080/13669870903233303 